\title{
KORRÓZIÓ VIZSGÁLATOK ALAPJAI
}

\section{THE BASES OF CORROSION'S INVESTIGATIONS}

\author{
Haraszti Ferenc \\ Óbudai Egyetem, Bánki Donát Gépész és Biztonságtechnikai Mérnöki Kar, \\ Gépészeti és Biztonságtudományi Intézet, Cím: 1081, Magyarország, Budapest \\ Népszínház utca 8.
}

\begin{abstract}
The corrosion behaviour is really complex. That's its definition and measurement is difficult. The most important methods and thesis are written in this article without complete introduction, based on the literature of corrosion.

Keywords: corrosion, steel, stainless steel.

\section{Összefoglalás}

A korróziós folyamatok igen összetett jelenségek. Ebből következően jellemzésük, mérhetőségük is nehéz, nagy felkészültséget igénylő feladat. A tanulmány célja -a teljesség igénye nélkül- bemutatni a legfontosabb módszereket, irányelveket az alapvető korróziós jelenségek jellemzésére.
\end{abstract}

Kulcsszavak: korrózió, acél, korrózióálló acél.

\section{Bevezetés}

Mióta az ember fém eszközöket használ, azóta küzd a korrózió okozta problémákkal. Igaz ez a megállapítás a szénacéloktól a nemesfémekig. Elektródpotenciáljuk szerint nemesfémeket és közönséges fémeket különböztetünk meg [1]. Bár a korróziós folyamatok elleni védekezés az elmúlt évtizedekben nagyságrendi és minőségi változáson ment keresztül, az egyre nagyobb számban gyártott fémszerkezetek és berendezések megkövetelik a tudományág állandó kutatását és fejlesztését a minél kisebb korróziós veszteségek eléréséhez. Egyes becslések szerint a világ acél termelésének 20 százaléka végzi rozsdaként pályafutását. Ez világviszonylatban óriási kár, ha lefordítjuk a számok nyelvére: sok milliárd amerikai dollárról van szó. Pontos számot lehetetlenség mondani globális és rendszeres felmérések nélkül. A korrózió, mint kémiai reakció pontos jellemzése nehéz feladat. Kijelenthetjük: ahány korróziós folyamat létezik, szinte annyi vizsgálati módszer is. Minden eset más és más nincs két ugyanúgy lejátszódó folyamat. A korrózió állóság tekintetében még a nemesfémek sem tökéletesek. E jelenség megközelítése egy komplex feladat.

A felosztása is három nagy területre oszlik. Létezik tisztán kémiai korrózió, vegyes korrózió, elektrokémiai korrózió. Ez utóbbi a jelentősebb a környezeti és az ipari gyakorlatban. Ahhoz, hogy elkerüljük a baleseteket, katasztrófákat és a nagy anyagi veszteségeket, elengedhetetlenül szükséges ezeket a folyamatokat felismernünk és jellemeznünk valamilyen mérőszámmal. A felismeréshez legtöbbször elégséges a fémben történő változást leírnunk. Ezt kvalitatív eljárásnak hívja a 
korróziós tudomány szakmai nyelvezete. Tulajdonképpen egy egyszerü vizuális megfigyelésről van szó, amely viszont igen jól használható felületi rozsdásodás esetén. Nem alkalmas ugyanakkor kristályhatárok mentén (a fém belsejében) kialakuló állapotok jellemzésére. Ahhoz, hogy következtetni tudjunk a teljes tönkremenetel állapotára, mérhető adatokra van szükségünk. A korróziós szakember feladata mindig egy korróziós méröszám megalkotása és ez ütközik nehézségekbe. Hiszen a fémek tönkremenetelét számos tényező befolyásolja. Egy kvalitatív (számszerü) mértéket megállapítani igen összetett feladat és nem is fejezi ki pontosan a folyamat jellegét. Tehát a korrózióérzékenység jellemzéséhez egy úgynevezett korróziósebességet kell megállapítanunk. Sajnos a folyamatok bonyolult sokaságára való tekintettel nem létezik egységesen jellemző mérőszám. A mérések általában csak egy adott, körülhatárolt kérdésre adnak választ. Tudniillik még laboratóriumi körülmények között ugyanolyan feltételekkel és tudományosan kivitelezett kísérletekkel sem reprodukálhatók mindig ugyanolyan eredménnyel. Csak bizonyos mérési határok között, hibahatárok megadásával következtethetünk egy-egy folyamat egészére. A természetben vagy ipari körülmények között a befolyásoló tényezök nagy száma - relatív páratartalom, hőmérséklet, $\mathrm{pH}$ érték, változó összetételü fémtartalom, különböző igénybevételek miatt ez a feladat még nehezebb. Mégis törekedni kell a minél sokoldalúbb vizsgálatra, hogy megfelelö következtetéseket tudjunk levonni a fém végleges tönkremenetelét illetően.

\section{Graviometria}

A legáltalánosabb módszer, amikor azt vizsgáljuk, hogy a fém mekkora hányada alakult át a korróziós folyamat következtében oxidokká, sókká esetleg fémes anyagokká. Ilyenkor azt elemezzük, hogy az illető anyag mennyit vesztett a súlyából vagy gyarapodott (graviometria). Megadhatjuk ezt a csökkenést (növekedést) $\mathrm{g} / \mathrm{m}^{2}$-ben, de önmagában ez még nem jelent sokat, ha nem időegységre vonatkoztatunk. Az összefüggésbe egy harmadik változót is számításba kell venni az időt. A folyamat sebességétől függően dolgozhatunk $\mathrm{g} / \mathrm{m}^{2}$. óra vagy $\mathrm{g} / \mathrm{m}^{2}$.nap vagy $\mathrm{g} / \mathrm{m}^{2} \cdot \mathrm{év}$ összefüggésekkel. Ekkor kapunk egy számítási modellt a korrózió kinetikájának leírására. Az iparban azonban a gyártást felügyelő mérnökök elsősorban arra kíváncsiak, hogy az általuk müködtetett fém berendezés mennyi ideig használható balesetmentesen. Ezért tehát az előző összefüggést átalakíthatjuk mm/év formába is, mely méretezési alapként szolgál a falvastagságra. Ezzel egy sokkal használhatóbb dimenziót alkottunk, mellyel már lehet elöre látni és tervezni. Nem alkalmazható ez a metódus, ha nem egyenletes korrózióról, hanem a lokális korróziós típusok egyikéről van szó. Ebben az esetben kitüntetett helyeken ugyanis lehetséges a fém teljes tönkremenetele a súlyveszteség (gyarapodás) viszont alig enged következtetni az egész szerkezet állapotára. Nem mond semmit a graviometria módszere a már említett fémen belüli korrodáltságról, amikor a kristályokon belül történik elváltozás. Ebben az esetben súlycsökkenést szinte lehetetlen mérni annyira kismértékü, viszont az egyik legveszélyesebb korróziós forma, ezért más módszer szükséges a már szerkezeti hibát okozó folyamat feltárására.

\section{Ellenállás mérés alapú vizsgálat}

Megfigyelhetjük ezeket a folyamatokat a fémek vezetőképességének szempontjából is. A fémek korrózió okozta oldódása közben ugyanis a keletkezett első és másodlagos korróziótermékek 
megváltoztathatják az anyag elektromos tulajdonságait. Erre a fajlagos ellenállás megváltozásából következtethetünk leginkább. A mérési módszer sorozatvizsgálatok elvégzésére is alkalmas. Főleg huzalokon végzik és hosszú, de vékony keresztmetszetü alkatrészeken is kivitelezhető. A fizikai elv a következő:

$$
R=\varrho \frac{\boldsymbol{l}}{\boldsymbol{A}}[\Omega]
$$

ahol:

Q a fajlagos ellenállás,

$\boldsymbol{l}$ a vezető hossza,

$\boldsymbol{A}$ pedig a vezető keresztmetszete.

Ha a korrózió a felületre egyenletesen hat, az elektrokémiai kölcsönhatások miatt a huzal keresztmetszete vékonyabb lesz. A keresztmetszet nagysága és az ellenállás érték egymással fordított arányban áll ezért az ellenállás megnő. Ezt mérhetjük egy egyszerü ellenállás mérővel, képet kapva a korrodálás mértékéről. A módszer alkalmas a már említett kristályközi elváltozás kimutatására is, ugyanis ekkor mindig megváltozik a fajlagos ellenállás (@) az anyag belsejében. További előnye még az automatizálhatósága. A korróziós folyamat mérhetőségét ilyenkor maga az ellenállás érték adja a következőképpen [2]:

$$
K=\frac{\varrho_{0}-\varrho_{1}}{\varrho_{0}} \cdot 100[\%]
$$

ahol:

K a korrózió,

@o az eredeti fajlagos ellenállás,

$\varrho_{1}$ megváltozott ellenállás.

Következő fontos

terület vizsgálatainkban a nem látható, az anyag belsejében létrejövő korróziós elváltozások precíz feltérképezése, mérése, mint erre már röviden utaltam az előzőekben. Ez a legveszélyesebb, legalattomosabb tönkremenetel fajta is egyben. Tekintsük át a szemcsehatáron (interkrisztallin) esetleg a kristályszemcséken (transzkrisztallin) keresztül keletkező korrózió előfordulási okait. Elsősorban ausztenites szövetszerkezettel rendelkező saválló acéloknál fordulhat elö, illetve nagy szilárdságú alumíniumötvözeteknél is megfigyelték már. A nagyon tiszta, szennyezőktől mentes fémeknél kizárható. A korróziós jelenség a szemcsehatárokon indul a felület közelében, innen halad az anyag mélyebb rétegei felé. A folyamat gyakorlatilag láthatatlan, speciális, nem megszokott korróziós vizsgálatokat kell elvégeznünk feltárására, előrehaladottságának dimenzionálására. A szemcseközi korrodáltság tulajdonképpen egy mikro repedés vagy ezek halmaza, mely kedvezőtlenül befolyásolja az anyag mechanikai, szilárdsági tulajdonságait. Kézenfekvő tehát, hogy azt mérjük, ami változik. Ezek a mechanikai sajátságok, amik az anyagban megváltoznak, segítenek a korrózió mértékének számszerü feltérképezésében. Egy fémből készült szerkezet méretezéséhez precízebb és biztonságosabb is ez a megoldás. Nem lehet tudniillik összevetni a szerkezet felületén keletkezett méretcsökkenés mértékét a fém belsejében történt elváltozásokkal. Nagyságrendi hibákat véthetünk, ha rosszul választjuk meg a folyamatra jellemző korróziósebességet (1. ábra).

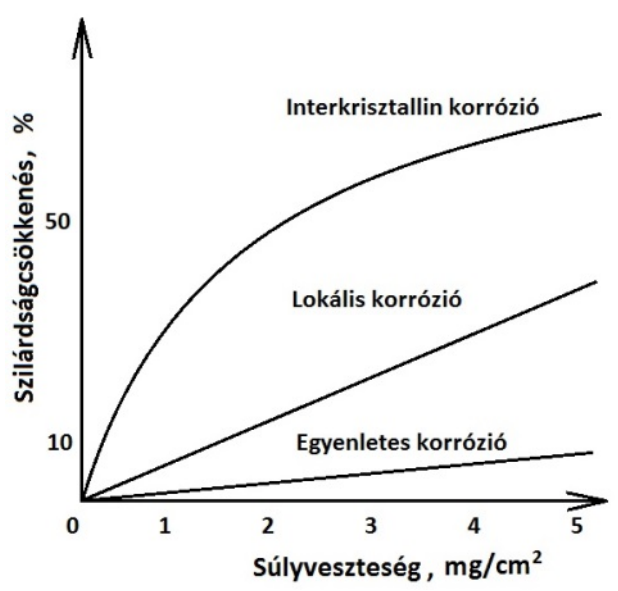

1. ábra. Jellemzö korróziós sebességek [2] 
A szerkezeti anyagok mechanikai vizsgálatai közé tartozik a szakítószilárdság és a nyúlás csökkenésének vizsgálata. Leggyakrabban ezek segítségével jellemezzük a korróziós folyamat állapotát. Ezeket a már jól ismert módszereket szabványok rögzítik. A vizsgálandó anyagból megfelelő számú mintát (próbatestet) kell biztosítani és elvégezni a mechanikai méréseket. A korróziós igénybevétel után megint meghatározzuk a mechanikai tulajdonságokat és az itt kapott értékekből fejezhetjük ki a változás mértékét százalékosan. Mivel vizsgálataink célja mindig egy korróziós sebesség meghatározása, érdemes időegységenként elvégezni a méréseket és ábrázolni azokat korrózió-idő diagramban. A korróziós folyamat mechanikai szempontból történő legfontosabb mérőszámai tehát [2]:

$$
K_{s z}=\frac{\sigma_{0}-\sigma_{1}}{\sigma_{0}} \cdot 100 \%
$$

ahol:

$\mathrm{K}_{\mathrm{sz}}$ a korrózió szakítószilárdság szerinti mértéke,

$\sigma_{0}$ a vizsgált fém eredeti szakítószilárdsága,

$\sigma_{1}$ a vizsgált fém korrózióval terhelt szakítószilárdsága [2].

$$
K_{n y}=\frac{\delta_{0}-\delta_{1}}{\delta_{0}} \cdot 100 \%
$$

ahol:

$\mathrm{K}_{\text {ny }}$ a korrózió nyúláscsökkenés szerinti mértéke, $\delta_{0}$ a fém eredeti nyúláscsökkenése,

$\delta 1$ a fém korrózióval terhelt nyúláscsökkenése.

A kristályközi korrózió megállapítására egyes, speciális esetekben használatos még a keménység mérés, ütőmunka meghatározás, és a nyomószilárdsági jellemzők meghatározása.

\section{Következtetések}

Cikkemben igyekeztem összefoglalni, áttekintést nyújtani a legfontosabb korróziós vizsgálati módszerek irányelveiről, meghatározásainak módszereiről. Vázoltam a tudományág sokrétüségét felismerésének, mértékbe állításának nehézségeit. Láthatóvá tettem a korrózió okozta károk megfigyelésének komplexitását, szabványba öntésének bonyolultságát. Minden korróziós, fém oxidációs probléma egyedi eset, amely gondos tervezést, elemzést, nagy elméleti felkészültséget kíván. Körültekintően kell eljárni, mely vizsgálat tükrözi legpontosabban a korróziós károk nagyságát, időbeni lefolyását.

\section{Szakirodalmi hivatkozások}

[1] Kovács-Coskun T., Völgyi B., Sikari-Nágl I.: Kontaktkorróziós jelenség tanulmányozása acél aluminium párositásánál, Müszaki Tudományos Füzetek EME kiadó, Kolozsvár, 2013, 201-204.

[2] Holló Mária: Korróziós vizsgálatok Müszaki Könyvkiadó Budapest, 1964.

[3] Dr. Kovács Klára: Korróziós alapfogalmak Müszaki Könyvkiadó Budapest, 1965. 